\title{
Removal of Trihalomethanes from Water using Modified Montmorillonite
}

\author{
Majid Hamouni Haghighat ${ }^{1}$ and Ali Mohammad-Khah ${ }^{1,2, *}$ \\ ${ }^{1}$ Department of Chemistry, Faculty of Science, University of Guilan, Rasht, Iran, P.O. Box 41635-19141 \\ ${ }^{2}$ Department of Water and Environmental Engineering, Caspian Sea Basin Research Center, University of Guilan, \\ Rasht, Iran, P.O. Box 41635-1914 \\ * Corresponding author: E-mail: mohammadkhah@guilan.ac.ir \\ Tel: +98-13-33343630-5(Ext.218), Fax: +98-13-33367262
}

Received: 01-12-2020

\begin{abstract}
Trihalomethanes (THMs) are formed during the water chlorination process through the reaction between chlorine and the organic materials. In this research, montmorillonite (MMT) and its modified form were used to remove the THMs from the water. The optimum conditions for the best adsorption capacity were evaluated using the Taguchi design of experiments. The result of comparing MMT with its modified sulfonated form (SMMT) indicated that SMMT is a more effective adsorbent than MMT. The evaluations showed that the optimum conditions for the THMs removal occur at $20^{\circ} \mathrm{C}, 10 \mathrm{mg}$ of adsorbent, $1 \mathrm{mg} / \mathrm{L}$ of THMs concentration, and $120 \mathrm{~min}$ for the adsorption time. The maximum adsorption capacity of $\mathrm{CHCl}_{3}, \mathrm{CHBrCl}_{2}, \mathrm{CHBr}_{2} \mathrm{Cl}$, and $\mathrm{CHBr}_{3}$ was achieved: $0.49,0.45,0.43$, and $0.38 \mathrm{mg} / \mathrm{g}$ at $C_{0}=0.10 \mathrm{mg} / \mathrm{L}$; $1.71,1.62,1.56$, and $1.45 \mathrm{mg} / \mathrm{g}$ at $C_{0}=0.50 \mathrm{mg} / \mathrm{L}$; and $4.43,4.35,4.23$, and $3.67 \mathrm{mg} / \mathrm{g}$ for $C_{0}=5.00 \mathrm{mg} / \mathrm{L}$, respectively. The THMs adsorption was compared between SMMT, powdered activated carbon (PAC), and granular activated carbon (GAC) and the results showed that SMMT is as effective as PAC and better than GAC and its production cost is lower than for the activated carbon.
\end{abstract}

Keywords: Acivated carbon; adsorption; clay; isotherm; langmuir; modification; montmorillonite; taguchi; trihalomethanes

\section{Introduction}

Trihalomethanes (THMs) are a group of chemicals which are the product of substituting the halogen atoms (F, $\mathrm{Cl}, \mathrm{Br}, \mathrm{I})$ with three hydrogen atoms of methane. Studies have confirmed that in certain conditions, the water chlorination process creates the four well-known components including the chloroform (trichloromethane; $\mathrm{CHCl}_{3}$ ), bromodichloromethane $\left(\mathrm{CHBrCl}_{2}\right)$, dibromochloromethane $\left(\mathrm{CHBr}_{2} \mathrm{Cl}\right)$, and bromoform (tribromomethane; $\left.\mathrm{CHBr}_{3}\right){ }^{1}$

The humic substances are the organic materials, which are widely spread in the aquatic environment. They are the major components of the natural organic matter and one of the important precursors of the THMs, most of which cannot be removed by the usual treatment processes. Because these materials produce the mutagenic and carcinogenic organic halogenated compounds during the chlorination of water, the THMs' removal from the drinking water is a critical undertaking. ${ }^{2}$
Researches have shown that the chloroform influences the respiratory system and it can trigger some respiratory allergies. Considering the other known side-effects of THMs such as liver and kidney damages, their effect on the reproduction, and their damaging effects on the nervous system and blood circulation, ${ }^{3}$ there is no doubt about the health risk of THMs. THMs were categorized as class A carcinogen by the United States Environmental Protection Agency (USEPA) and the World Health Organization (WHO) in 1975. Both organizations emphasized on the necessity of removing these compounds from the drinking water. The USEPA guideline for the total THMs is $80 \mu \mathrm{g} / \mathrm{L}$, while the guideline of WHO is $560 \mu \mathrm{g} / \mathrm{L} .{ }^{3,4,5}$

Since 1980 ample research has been conducted on the removal of THMs and its precursors, and the THMs removal through the adsorption has been changed to an interesting subject. The powdered activated carbon (PAC) and the granular activated carbon (GAC) are widely employed as the industrial adsorbents of the THMs. ${ }^{6,7,8} \mathrm{Ad}-$ 
sorbents such as activated carbon fibre, ${ }^{9}$ modified synthetic carbon ${ }^{10}$ carbon nanotubes, ${ }^{11}$ and nano- $\mathrm{TiO}_{2}{ }^{12}$ have also been studied.

The removal of the hazardous material by clays has been considered during the last 20 years, due to their low cost and high efficacy. Like the clay, the montmorillonite (MMT) could be an appropriate adsorbent for removing cations, heavy metals, and organic matter because of its special adsorption properties, the modification abilities, the low price, and availability. MMT is a set of dense layers with few nanometres close to each other and also the sodium or calcium cations as the interlayer ions. The structure of each layer of MMT consists of two types of octagonal and tetrahedral structural sheets. Each layer consists of an octahedral sheet located between two tetrahedral sheets. Water molecules, calcium, or sodium ions are between the two layers. ${ }^{13}$ The modification of MMT changes its efficiency, and the acid modification is one of the improved methods to increase its adsorption capacity and catalytic properties. MMT is cheap, its modification process with acid has low cost and the price of the sulfonated montmorillonite (SMMT) is lower than the activated carbon. Ravichandran and Sivasankar used hydrochloride acid-activated MMT as a catalyst for the isopropylation of benzene. ${ }^{14}$ The modification of montmorillonite clay with the 2-mercaptobenzimidazole and the investigation of their antimicrobial properties, ${ }^{15}$ the sorption of naphthalene onto the modified MMT, ${ }^{16}$ and the sorption of heavy metals from the automobile effluent ${ }^{17}$ are examples of the acid-modified MMT applications.

Also, MMT and its modified forms were used to adsorb the sulfamethoxazole and tetracycline, ${ }^{18}$ chromium(IV) retention, ${ }^{19}$ cationic dyes, ${ }^{20}$ tetracycline antibiotics, ${ }^{21}$ acid Red 17,22 calcium ion and bisphenol $\mathrm{A},{ }^{23}$ bisphenol $\mathrm{A},{ }^{24}$ rhodamine and hexavalent chromium, ${ }^{25}$ thiabendazole, ${ }^{26}$ and soil humic acid. ${ }^{27}$

In this study, the effects of MMT and its modified forms with the chlorosulfonic acid (SMMT) were evaluated for the adsorption of the THMs. Finally, the important factors such as the temperature, contact time, adsorbent amount, and the initial THMs concentrations were optimized by the Taguchi design of experiments. ${ }^{28}$ Furthermore, the adsorption of THMs on the MMT and SMMT were compared for the powdered and granular activated carbon. The adsorption mechanism and the adsorption isotherms were also studied.

\section{Experimental}

\section{1. Preparation of SMMT and THMs Solutions}

Chlorosulfonic acid (Merck KGaA, Darmstadt, Germany) was used for the sulfonation of MMT (calcium form) with the dimensions of 1-2 nm (Sigma-Aldrich, St. Louis,
Missouri, United States) through the modification of the method developed by Shirini, Mamaghani and Atghia. ${ }^{29}$ $100 \mathrm{~mL}$ beaker was filled with $1 \mathrm{~g}$ MMT, and $0.3 \mathrm{~g}$ chlorosulfonic acid was added slowly over a period of $30 \mathrm{~min}$ and the mixture was agitated by a glass rod. The beaker was put in an ice bath during the sulfonating period. After the sulfonating step, the product was dried for $3 \mathrm{~h}$ at $90{ }^{\circ} \mathrm{C}$ and then it was kept in a desiccator for the subsequent uses.

Based on the theory, there are $2.14 \mathrm{mmol}$ sulfonic groups per $1 \mathrm{~g}$ SMMT. To determine the SMMT acidity, 50 $\mathrm{ml}$ of $\mathrm{NaOH}(0.1 \mathrm{M})$ was added to a $250 \mathrm{ml}$ flask and the reaction product of $1 \mathrm{~g}$ MMT and $0.3 \mathrm{~g}$ sulfonic acid was added to the solution. The flask was placed on a shaker at $150 \mathrm{RPM}$ for $2 \mathrm{~h}$, and the solution was titrated with $0.1 \mathrm{M}$ hydrochloric acid. Assuming that all the chlorosulfonic acid reacts with the MMT and the acidity belongs to the sulfonic groups, there is $2.00 \mathrm{mmol}$ of sulfonic groups per gram of SMMT.

Scanning electron microscopy (SEM) (S-4160, Hitachi, Japan) was performed to determine the surface characterisation of MMT and SMMT. A very thin coating of gold was placed on the samples by sputtering at an accelerating voltage of $15 \mathrm{kV}$. The Fourier Transform Infrared (FTIR) spectra in the ATR mode were recorded using Magna-IR 560, Nicolet Ltd., England, in the range of 2000 to $650 \mathrm{~cm}^{-1}$ with 8 scans and a resolution of $2 \mathrm{~cm}$.

$\mathrm{X}$-ray diffraction (XRD) analysis was performed using XRD (INEL, Equinox 3000, France) diffractometer with $\mathrm{Cu}$ - $\mathrm{Ka}$ radiation.

The required solutions with different concentrations were prepared by diluting $2000 \mu \mathrm{g} / \mathrm{mL}$ standard solution of the THMs (Supelco Inc. Bellefonte, PA, USA). The concentrations of $\mathrm{CHCl}_{3}, \mathrm{CHBrCl}_{2}, \mathrm{CHBr} 2 \mathrm{Cl}$, and $\mathrm{CHBr}_{3}$ were equal and the deionized water with a conductivity of less than $0.5 \mu \Omega / \mathrm{cm}$ was used for the dilution.

\section{2. Design of the Experiments to Determine the Optimum Conditions using the Taguchi Design}

The Taguchi design is a designed experiment that lets one choose a product or process that functions more consistently in the operating environment. The Taguchi design recognizes that all factors that cause variability could not be controlled. These uncontrollable factors are called the noise factors. The Taguchi design tries to identify the controllable factors (control factors) that minimize the effect of the noise factors. During the experimentation, one manipulates the noise factors to force the variability to occur and then identify the optimal control factor settings that make the process or product robust, or resistant to variation from the noise factors. A process that has been designed with this goal would produce more consistent output and would deliver more consistent performance regardless of the environment in which it is used. ${ }^{30}$ Using the Minitab software (Minitab Inc., PA, USA) and the design of 
experiments based on the Taguchi design, a number of tests for the four control factors, i.e., the adsorption temperature, the contact time, the adsorbent amount, and the initial concentration of THMs were run at three levels: adsorption temperature $\left(10,20\right.$, and $\left.30^{\circ} \mathrm{C}\right)$, contact time $(10$, 60 , and $120 \mathrm{~min}$ ), amount of adsorbent $(10,25$, and $50 \mathrm{mg}$ ), and the total concentration of THMs $(0.1,0.5$, and $1 \mathrm{mg} / \mathrm{L})$. The effect of $\mathrm{pH}$ was not considered and all samples were prepared at neutral $\mathrm{pH}$, because the water $\mathrm{pH}$ in water treatment plants is 6.5 to 7.5 and the $\mathrm{pH}$ of the water after chlorination was also in the same range. ${ }^{31}$ Nine tests were performed according to the specified factors and levels. Each test was repeated three times, and the average of the results was used for the next calculations. The water temperature levels were set based on the average water temperature of the treatment plants at different seasons of the year in the northern part of Iran. The THMs levels were determined based on the USEPA and WHO guidelines.

\section{3. Batch Adsorption Tests}

Considering the design of the experiments with the Taguchi design, the test conditions were determined in accordance with Table 1.

Table 1. Batch adsorption test conditions based on the Taguchi design of the experiment

\begin{tabular}{ccccc}
\hline Run & $\begin{array}{c}\text { Adsorbent } \\
(\mathbf{m g})\end{array}$ & $\begin{array}{c}\text { Temperature } \\
\left({ }^{\circ} \mathbf{C}\right)\end{array}$ & $\begin{array}{c}\text { Total THMs } \\
\text { concentration }(\mathbf{m g} / \mathbf{L})\end{array}$ & $\begin{array}{c}\text { Time } \\
(\mathbf{m i n})\end{array}$ \\
\hline 1 & 10 & 10 & 0.1 & 10 \\
2 & 10 & 20 & 0.5 & 60 \\
3 & 10 & 30 & 1 & 120 \\
4 & 25 & 10 & 0.5 & 120 \\
5 & 25 & 20 & 1 & 10 \\
6 & 25 & 30 & 0.1 & 60 \\
7 & 50 & 10 & 1 & 60 \\
8 & 50 & 20 & 0.1 & 120 \\
9 & 50 & 30 & 0.5 & 10 \\
\hline
\end{tabular}

The adsorbent was poured into $200 \mathrm{~mL}$ Erlenmeyer flask and the THMs solution was added. The flask opening was covered with parafilm and it was placed in a refrigerator shaker incubator (NB-205VL, N-BIOTEK, Korea) at 120 RPM. After the adsorption period, the concentrations of the THMs were determined by gas chromatography (Younglin, Korea) equipped with the Pulsed Discharge Electron Capture Detector (PDECD). Helium as the carrier gas with the flow of $6 \mathrm{~mL} / \mathrm{min}$, dopant gases (a mixture of $3 \%$ xenon in helium) with the flow rate of $3 \mathrm{~mL} / \mathrm{min}$, and a one-meter column of the same type as the main column (as pre-column to protect the main column) were used. Two microliters of the aqueous samples were injected using a split method with a ratio of one to five. The injector and the detector temperatures were set at $180^{\circ} \mathrm{C}$ and
$200{ }^{\circ} \mathrm{C}$, respectively. Furthermore, the oven temperature was set at $90^{\circ} \mathrm{C}$ for $3 \mathrm{~min}$ and then increased at $10^{\circ} \mathrm{C} / \mathrm{min}$ to $120^{\circ} \mathrm{C}$. Consequently, it remained at this temperature for 3 min..$^{32}$ In all cases, the THMs control solution without adsorbent was used to eliminate the effect of the factors other than the adsorption. ${ }^{33}$ GAC (Merck, Darmstadt, Germany, with granular size about $1.5 \mathrm{~mm}$, Merck No. 102514), PAC (Merck, Darmstadt, Germany, with particle size under $100 \mu \mathrm{m}$, Merck No. 122186), MMT and SMMT were used as the adsorbents.

\section{4. Adsorption Isotherms}

Two well-known equations, i.e., the Langmuir and Freundlich equations describe the adsorption isotherms and they could be applied to the solid/liquid system. These two isotherms were used to study the THMs adsorption onto the SMMT. The Langmuir model is based on the monolayer adsorption and it follows the equation (1):

$$
\frac{1}{\mathrm{q}_{\mathrm{e}}}=\frac{1}{\mathrm{a}}+\frac{1}{\mathrm{abC}_{\mathrm{e}}}
$$

Freundlich isotherm is based on the multilayer adsorption and it follows the equation (2):

$$
\log \mathrm{q}_{\mathrm{e}}=\log \mathrm{k}_{\mathrm{f}}+\frac{1}{\mathrm{n}} \log \mathrm{C}_{\mathrm{e}}
$$

In the equation (1), $C_{\mathrm{e}}$ is the concentration of the adsorbate at the equilibrium time, $q_{\mathrm{e}}$ is the equilibrium adsorption capacity of the adsorbent, and $\mathrm{a}$ and $\mathrm{b}$ are the Langmuir constants. Moreover, in the equation (2), $\mathrm{k}_{\mathrm{f}}$ and $\mathrm{n}$ are the Freundlich constants. To study the THMs adsorption isotherms, the THMs solutions with 8 different concentrations $(0.10,0.25,0.50,0.75,1.0,2.0,5.0$, and 10.0 $\mathrm{mg} / \mathrm{L}$ ) were prepared and eight $200 \mathrm{~mL}$ Erlenmeyer flasks were filled with $50 \mathrm{~mL}$ of each concentration of the THMs solution. The adsorption of THMs was measured after keeping for $150 \mathrm{~min}$ in the optimum conditions $(10 \mathrm{mg}$ adsorbent, $20^{\circ} \mathrm{C}$, and neutral $\mathrm{pH}$ ) and the data were used to study the THMs' adsorption isotherms.

\section{Results and Discussion 3. 1. Adsorption Properties of MMT and SMMT}

Given the fact that the modification is a means to increase the adsorption properties of the MMT, the sulfonic groups were added to the structure of the MMT by the chlorosulfonic acid. Figures 1 and 2 show the SEM images of MMT and SMMT, respectively. The comparison of the figures indicates that the MMT surface changed after the sulfonation. This change in the surface can be due to the sulfonation of the surface and the reduction of interlayer water. 


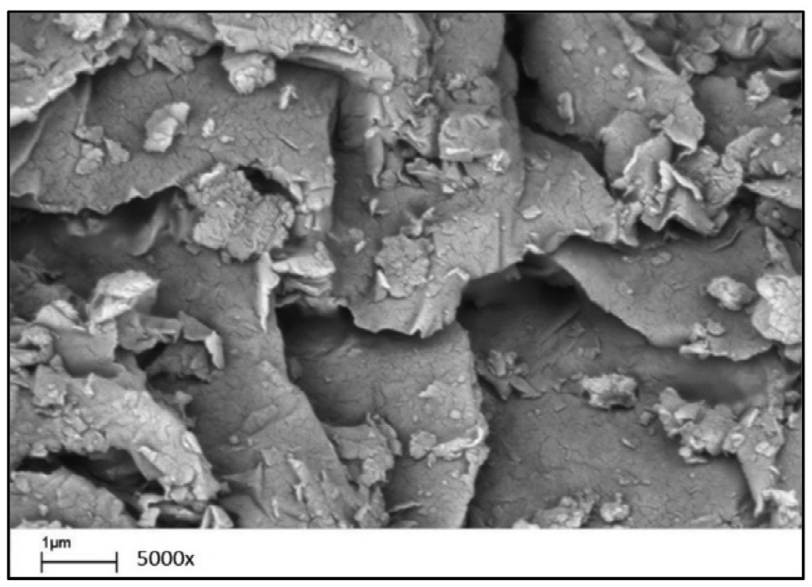

Figure 1. SEM image of MMT

Figure 3 shows the FT-IR spectra of MMT and SMMT. In the spectrum (a), the peak at $1047 \mathrm{~cm}^{-1}$ is related to the stretching vibration of $\mathrm{Si}-\mathrm{O}$ bond. The peak observed at $1640 \mathrm{~cm}^{-1}$ and the broad peak at $3420 \mathrm{~cm}^{-1}$ is the representation of crystalline water in MMT lattice. The peak at $3632 \mathrm{~cm}^{-1}$ could be attributed to the $\mathrm{OH}$ units in MMT. In the spectrum (b), the symmetric stretching vibration of $\mathrm{S}=\mathrm{O}$ bond appears at $1045 \mathrm{~cm}^{-1}$. The peak at $1058 \mathrm{~cm}^{-1}$ is related to the overlap of the asymmetric stretching vibration of $\mathrm{S}=\mathrm{O}$ and stretching vibration of Si-O bonds. The peaks at 674 and $878 \mathrm{~cm}^{-1}$ are related to the stretching vibration of S-O bond. After the sulfonating, the interlayer water decreased and the peak at $1640 \mathrm{~cm}^{-1}$ disappeared (spectrum b) and the peak at $3314 \mathrm{~cm}^{-1}$ is related to the $\mathrm{OH}$ stretching vibration of $\mathrm{SO}_{2}-\mathrm{OH}$ (sulfonic groups). As a result, the sulfonation of the MMT is confirmed.

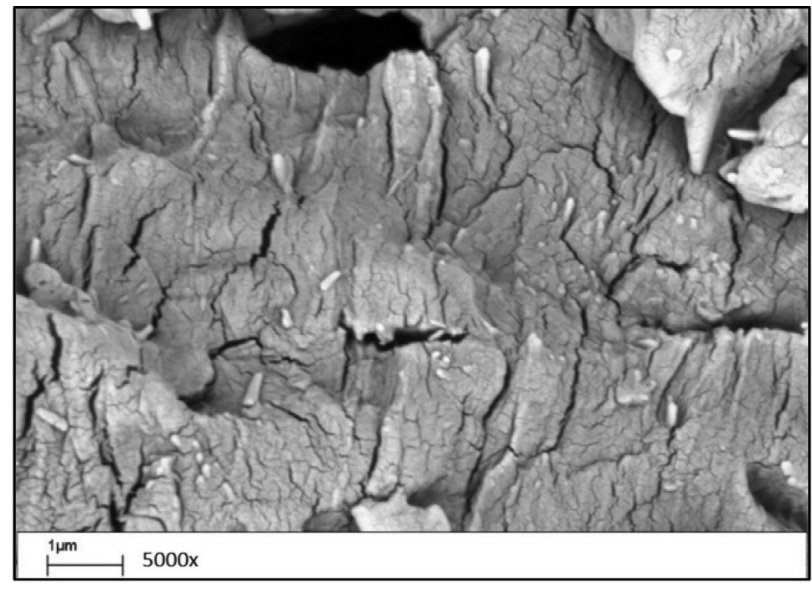

Figure 2. SEM image of SMMT

Figure 4 shows the XRD images of MMT and SMMT. Based on the XRD image results, the crystalline structure appears to have changed after the sulfonating.

To confirm the effect of the sulfonation on the adsorption, the batch adsorption tests on the MMT and the SMMT were conducted under the same conditions with the Taguchi design (Table 1) and the total THMs adsorption percentage for MMT and SMMT were calculated. The results are demonstrated in Table 2.

To study the significance of the differences between each pair of the data that are mutually linked, the Wilcoxon signed-rank test was run. ${ }^{34}$ The differences between them were significant $(p \leq 0.05)$.

Since in the seven out of the nine tests, the total amount of the THMs adsorption on SMMT were more than on the other adsorbent, the sulfonation led to positive

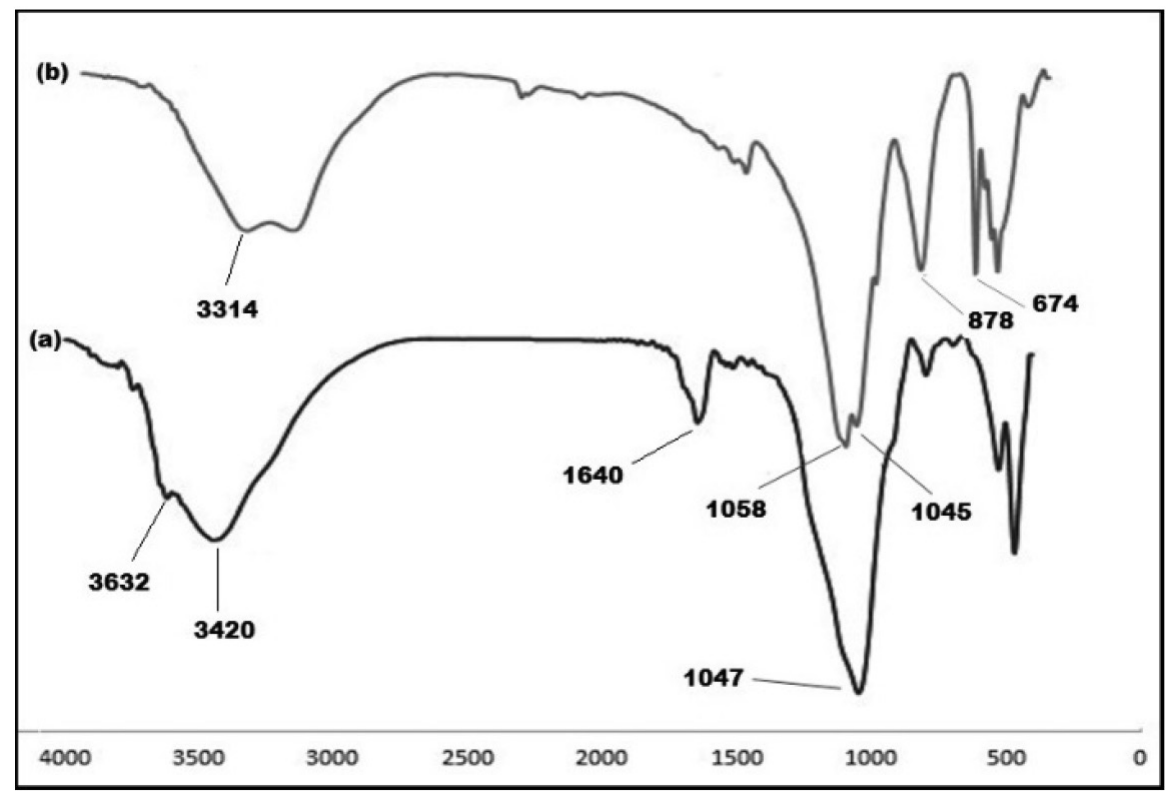

Figure 3. The FT-IR spectrum of MMT and SMMT 


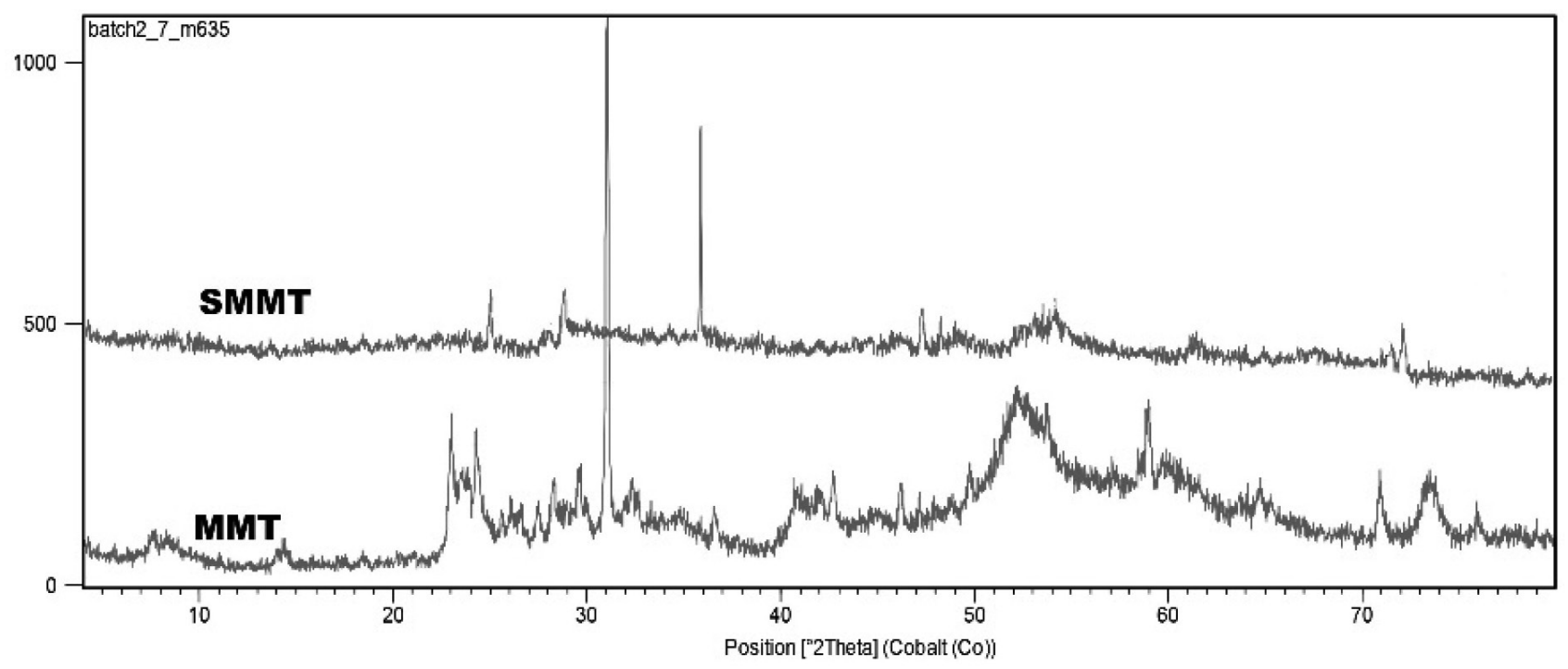

Figure 4. The XRD images of MMT and SMMT

Table 2. Batch adsorption test results based on the Taguchi design with the two adsorbents: MMT and SMMT

\begin{tabular}{ccc}
\hline Run No. & $\begin{array}{c}\text { Total adsorption } \\
\text { \% for MMT }\end{array}$ & $\begin{array}{c}\text { Total adsorption } \\
\text { \% for SMMT }\end{array}$ \\
\hline 1 & $20.3 \pm 0.6$ & $25.3 \pm 0.9$ \\
2 & $53.5 \pm 2.5$ & $74.0 \pm 1.6$ \\
3 & $75.0 \pm 2.4$ & $64.1 \pm 1.8$ \\
4 & $58.1 \pm 0.8$ & $64.2 \pm 1.5$ \\
5 & $28.2 \pm 1.3$ & $56.2 \pm 2.7$ \\
6 & $73.0 \pm 1.5$ & $69.8 \pm 2.8$ \\
7 & $62.0 \pm 2.5$ & $80.6 \pm 2.1$ \\
8 & $69.2 \pm 2.9$ & $84.3 \pm 3.1$ \\
9 & $39.6 \pm 0.8$ & $41.7 \pm 1.4$ \\
\hline
\end{tabular}

effects and it increased the adsorption and effectiveness of MMT. For further confirmation, the batch adsorption tests at the same conditions were conducted for the control factors (adsorbent: $10 \mathrm{mg}$ per $50 \mathrm{~mL}$ solution, THMs concentration $1 \mathrm{mg} / \mathrm{L}$, temperature $20^{\circ} \mathrm{C}$, and contact time 120 $\mathrm{min}$ ) and for the two adsorbents, and each test was repeat- ed 5 times. Also, the adsorption amount of THMs on the PAC and GAC (the two common adsorbents for the THMs removal) was determined and compared with MMT and SMMT. The results are shown in Table 3.

The result of the ANOVA (Analysis of Variance) test showed that there was a significant difference between the means of the two sets of data at $p \leq 0.05$ level of significance. As it was demonstrated in all of the 5 tests by SMMT, the total percentage of the THMs removal are more than at the other adsorbents, so the sulfonation increases the adsorption efficiency. Also, on average, $87 \%$ of the total THMs were removed by the sulfonated form (SMMT).

The average adsorption percentage for the PAC and GAC were $86.3 \%$ and $79.6 \%$, respectively. There was a significant difference between the means of the PAC and GAC adsorption data at $p \leq 0.05$ and PAC was a more effective adsorbent than GAC. However, there was no significant difference between the means for SMMT and PAC. Therefore, based on experimental conditions, SMMT is as effective as PAC and it is better than GAC for the THMs removal.

Table 3. Results of the THMs batch adsorption percentage at the same conditions for MMT, SMMT, PAC, and GAC

\begin{tabular}{lcccc}
\hline & $\begin{array}{c}\text { THMs } \\
\text { adsorption\% } \\
\text { on MMT }\end{array}$ & $\begin{array}{c}\text { THMs } \\
\text { adsorption\% } \\
\text { on SMMT }\end{array}$ & $\begin{array}{c}\text { THMs } \\
\text { adsorption\% } \\
\text { on PAC }\end{array}$ & $\begin{array}{c}\text { THMs } \\
\text { adsorption\% } \\
\text { on GAC }\end{array}$ \\
\hline Run 1 & 62.7 & 85.0 & 82.3 & 78.0 \\
Run 2 & 61.0 & 86.5 & 85.7 & 80.2 \\
Run 3 & 63.2 & 88.1 & 89.4 & 79.1 \\
Run 4 & 60.5 & 85.7 & 88.9 & 78.7 \\
Run 5 & 65.0 & 89.8 & 85.3 & 76.1 \\
Mean & 62.5 & 87.0 & 86.3 & 78.4 \\
Standard deviation & 1.8 & 1.9 & 2.9 & 1.5 \\
\hline
\end{tabular}




\section{2. The Effect of the Contact Time, Adsorption Temperature, Initial Concentration of THMs, and the Amount of the Adsorbent on the Adsorption of THMs}

Because of the better performance of the SMMT against MMT, SMMT was used in the further experiments. After the batch adsorption tests, which were run at the same conditions explained in Table 1, the adsorption capacity was calculated using the following equation (3):

$$
q=\frac{\left(C_{0}-C_{t}\right)}{M} V
$$

In this equation, $q$ is the adsorption capacity, $C_{0}$ is the initial THMs concentration, $C_{\mathrm{t}}$ is the THMs concentration after the adsorption, $M$ is the adsorbent amount and $V$ is the THMs solution volume. All data were entered into the Minitab software, and the optimum conditions were calculated using the "Larger is Better" option by analysing the Taguchi design. The results are shown in Figure 5.

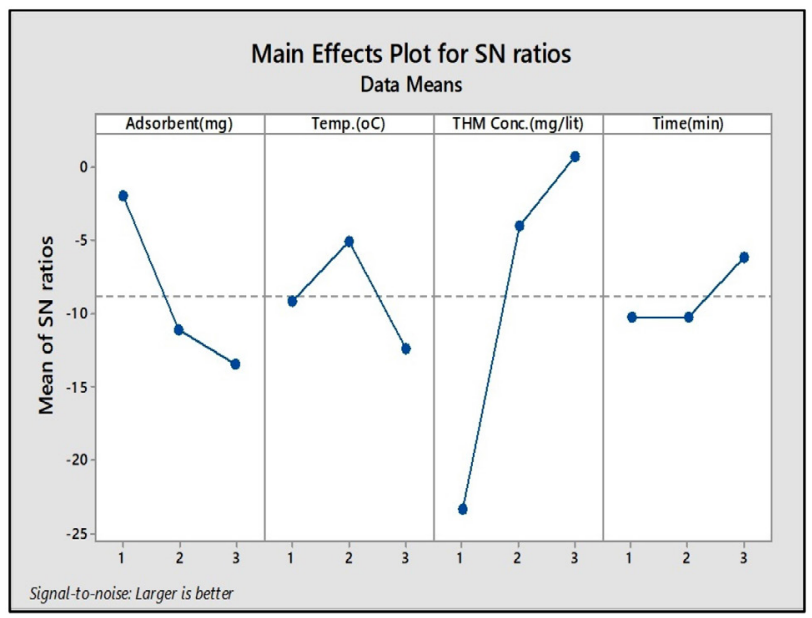

Figure 5. The results of the Taguchi design - adsorbent: $1=10,2=$ $25,3=50 \mathrm{mg}$; temperature: $1=10,2=20,3=30^{\circ} \mathrm{C}$; the total concentration of THMs $1=0.1,2=0.5$ and $3=1 \mathrm{mg} / \mathrm{L}$; and adsorption time: $1=10,2=60,3=120 \mathrm{~min}$. In each case the highest point indicates the optimum condition.

The optimum temperature to remove the THMs was $20^{\circ} \mathrm{C}$ and the minimum adsorption capacity was acquired at $30^{\circ} \mathrm{C}$. Since an increase in the temperature over $20^{\circ} \mathrm{C}$ leads to the decrease in the adsorption, it can be a sign of the physical adsorption on the surface of the adsorbent.

The analysis showed that the optimum adsorption capacity was obtained using $10 \mathrm{mg}$ SMMT that indicated the good performance of the adsorbent. Furthermore, as expected, the analysis showed that the optimum contact time was $120 \mathrm{~min}$. The Minitab calculation showed that the means of the signal to noise ratio $(\mathrm{S} / \mathrm{N})$ in the opti- mum condition was 14.2. The higher values of the $\mathrm{S} / \mathrm{N}$ identified the best control factor setting and the minimum uncontrollable factor. ${ }^{35}$ Moreover, the effect of the THMs contact time was determined via the three solutions with the initial and equal THMs concentrations of $0.1,0.5$, and a high concentration of $5.0 \mathrm{mg} / \mathrm{L}\left(C_{0}\right)$ and $10 \mathrm{mg}$ adsorbent at $20^{\circ} \mathrm{C}$ (the optimum conditions resulted from the Taguchi design for the adsorbent amount and temperature). The results are shown in Figures 6A, 6B and 6C.

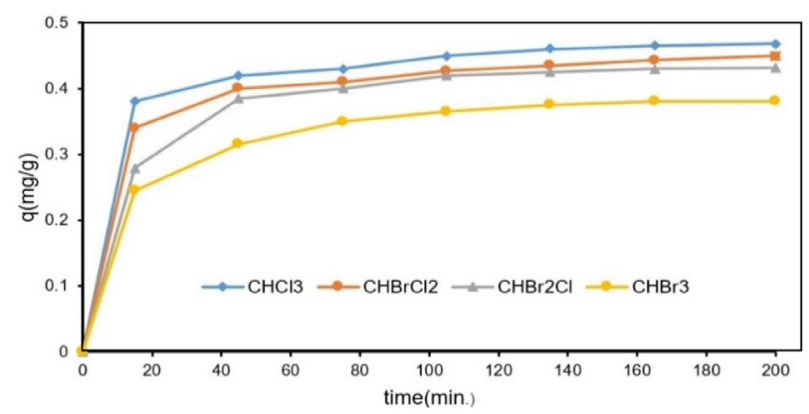

Figure 6A. Adsorption capacity of THMs over the time at the initial concentration of $0.1 \mathrm{mg} / \mathrm{L}$ and $10 \mathrm{mg}$ adsorbent at $20^{\circ} \mathrm{C}$

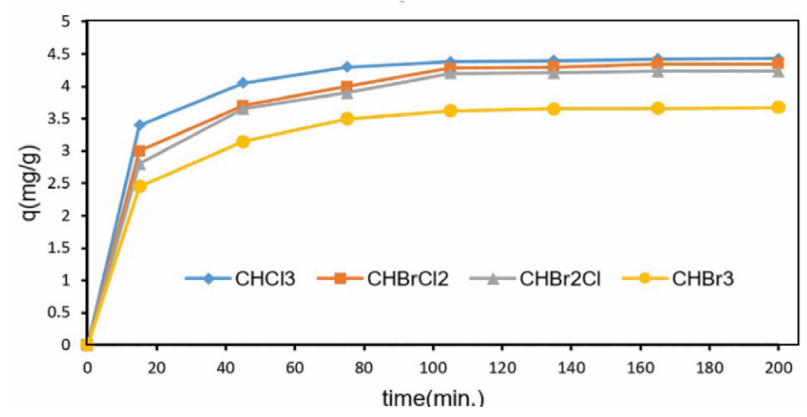

Figure 6B. Adsorption capacity of THMs over the time at the initial concentration of $0.5 \mathrm{mg} / \mathrm{L}$ and $10 \mathrm{mg}$ adsorbent at $20^{\circ} \mathrm{C}$

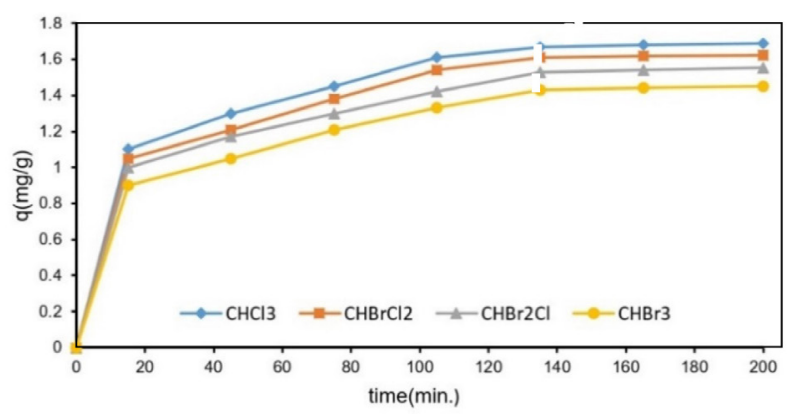

Figure 6C. Adsorption capacity of THMs over the time in the initial concentration of $5.0 \mathrm{mg} / \mathrm{L}$ and $10 \mathrm{mg}$ adsorbent at $20^{\circ} \mathrm{C}$

The maximum adsorption capacities of SMMT (mg/g) for $\mathrm{CHCl}_{3}, \mathrm{CHBrCl}_{2}, \mathrm{CHBr}_{2} \mathrm{Cl}$, and $\mathrm{CHBr}_{3}$ at the different initial concentrations of THMs $\left(C_{0}\right)$ are shown in Table 4. The equilibrium time was $165 \mathrm{~min}$ for $C_{0}=0.1$ $\mathrm{mg} / \mathrm{L}, 155 \mathrm{~min}$ for $C_{0}=0.5 \mathrm{mg} / \mathrm{L}$, and $120 \mathrm{~min}$ for $C_{0}=5$ $\mathrm{mg} / \mathrm{L}$. Since the increase of THMs concentration could in- 
Table 4. The maximum adsorption capacity of SMMT $(\mathrm{mg} / \mathrm{g})$ for $\mathrm{CHCl}_{3}, \mathrm{CHBrCl}_{2}, \mathrm{CHBr}_{2} \mathrm{Cl}$, and $\mathrm{CHBr}_{3}$ at different initial concentrations of THMs $\left(C_{0}\right)$.

\begin{tabular}{ccccc}
\hline$C_{\mathbf{0}}(\mathrm{mg} / \mathrm{L})$ & $\mathrm{CHCl}_{3}$ & $\mathrm{CHBrCl}_{2}$ & $\mathrm{CHBr}_{2} \mathrm{Cl}$ & $\mathrm{CHBr}_{3}$ \\
\hline 0.1 & 0.468 & 0.450 & 0.431 & 0.381 \\
0.5 & 1.711 & 1.623 & 1.555 & 1.449 \\
5 & 4.431 & 4.354 & 4.230 & 3.676 \\
\hline
\end{tabular}

crease the diffusion flux through the THMs solution to the adsorbent surface, the adsorption occurs more quickly. The adsorption of $\mathrm{CHCl}_{3}$ and $\mathrm{CHBr}_{3}$ on SMMT resulted in the highest and the lowest capacity. This indicates that smaller molecules are adsorbed better than others. Over $70 \%$ of the THMs were adsorbed in $50 \mathrm{~min}$, which shows the good adsorption efficiency of the adsorbent.

\section{3. Adsorption Mechanism}

According to the Brunauer-Emmett-Teller (BET) analysis of MMT and SMMT, the specific surface area of MMT and SMMT were obtained as 180.2 and $138.7 \mathrm{~m}^{2} / \mathrm{g}$, respectively. The specific surface area decreased after the sulfonating of MMT because the sulfonation has changed the surface. The $\mathrm{SO}_{3}$ groups cover the surface and the steric hindrance of the $\mathrm{SO}_{3}$ group could reduce the $\mathrm{N}_{2}$ adsorption on the surface of MMT. The larger group can further decrease the surface area. ${ }^{36,37}$

Several mechanisms could be proposed for adsorbing the organic matter on MMT as follows:

1- Physical adsorption-adsorption due to van der Waals' forces (the summation of the dipole-dipole interactions, the dipole-induced dipole interactions, and the induced dipole-induced dipole interactions).

2- Chemical adsorption

3- Hydrogen bonding

4- Coordination complexes 38

Given the nature of the THMs, the weak polarity of these molecules and the presence of the $\mathrm{OH}$ groups at the surface of MMT, it seems that the physical adsorption on the surface is done because of the van der Waals' forces. By the reaction of the surface of MMT with chlorosulfonic acid, the $\mathrm{SO}_{3}$ functional groups are replaced with the $\mathrm{OH}$ groups, van der Waals' interactions are enhanced and the adsorption is increased. Chloroform is more polar than the other THMs and this molecule has the highest adsorption. This can be a confirmation of the proposed adsorption mechanism. Since an increase in the temperature over $20^{\circ} \mathrm{C}$ leads to a decrease in the adsorption, it could be a sign of the physical adsorption mechanism on the surface of the adsorbent.

\section{4. THMs Adsorption Isotherms}

To determine the compatibility of the Langmuir or Freundlich isotherm with the THMs adsorption, the correlation coefficients of both lines were calculated according to the equations (1) and (2). The results are shown in Table 5.

The results showed that the correlation coefficients of the adsorption of the THMs on SMMT matched the Langmuir isotherm. All the correlation coefficients for the Langmuir isotherm were greater than 0.986 . In the Freundlich isotherm, the poorest match was observed with a correlation coefficient of 0.9711 for $\mathrm{CHCl}_{3}$. In the other THMs, the coefficients gradually became lower. Regarding the better match with the Langmuir isotherm, it could be stated that the maximum adsorption takes place on the surface of SMMT. The adsorption of THMs increases because the modification by chlorosulfonic acid affects the surface layers of MMT and enhances the van der Waals' forces. Considering the Freundlich isotherm, the correlation coefficients decreased from $\mathrm{CHCl}_{3}$ to $\mathrm{CHBr}_{3}$. The $\mathrm{CHCl}_{3}$ molecule is the smallest THM, so it diffuses better among the layers. For the molecules larger than the $\mathrm{CHCl}_{3}$, the multi-layer adsorption has decreased and in the case of the $\mathrm{CHBr}_{3}$ it is minimized. The Langmuir isotherm charts are shown in Figure 7.

\section{Conclusions}

The World Health Organization and the United States Environmental Protection Agency have emphasized the necessity of the trihalomethanes' removal from the drinking water, so removing them and their precursors from the water sources is essential. Montmorillonite is a low-cost adsorbent, and it can remove a large quantity of the organic and inorganic contaminants from the water. Its performance could be improved by the sulfonic acid mod-

Table 5. Constants and correlation coefficients of the Langmuir and Freundlich isotherms

\begin{tabular}{|c|c|c|c|c|c|c|}
\hline \multirow[b]{2}{*}{ THMs } & \multicolumn{3}{|c|}{ Langmuir isotherm } & \multicolumn{3}{|c|}{ Freundlich isotherm } \\
\hline & $\begin{array}{c}\text { Correlation } \\
\text { coefficient (R2) }\end{array}$ & $a(\mathrm{mg} / \mathrm{g})$ & b (L/mg) & $\begin{array}{c}\text { Correlation } \\
\text { coefficient (R2) }\end{array}$ & kf (mg/g) & $\mathbf{n}(\mathbf{L} / \mathbf{m g})$ \\
\hline $\mathrm{CHCl}_{3}$ & 0.9993 & 0.2698 & $8.85 \times 10^{-3}$ & 0.9711 & $4.41 \times 10^{-3}$ & 1.09 \\
\hline $\mathrm{CHBrCl}_{2}$ & 0.9865 & 0.2621 & $7.51 \times 10^{-3}$ & 0.9654 & $3.84 \times 10^{-4}$ & 1.38 \\
\hline $\mathrm{CHBr}_{2} \mathrm{Cl}$ & 0.9895 & 0.2519 & $6.07 \times 10^{-3}$ & 0.9593 & $3.73 \times 10^{-4}$ & 2.41 \\
\hline $\mathrm{CHBr}_{3}$ & 0.9947 & 0.2023 & $5.50 \times 10^{-3}$ & 0.8546 & $3.47 \times 10^{-4}$ & 5.23 \\
\hline
\end{tabular}



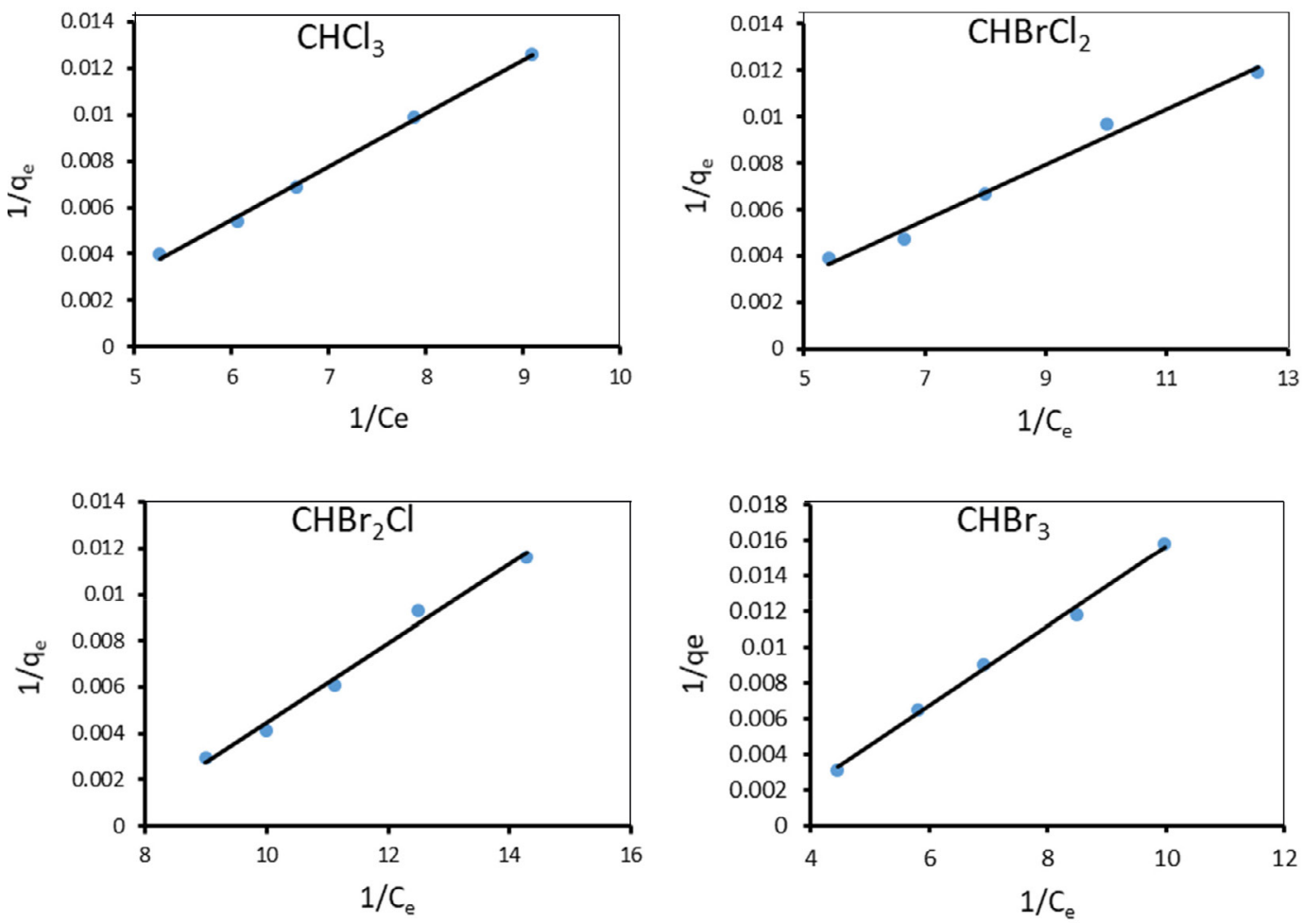

Figure 7. The Langmuir isotherm charts for THMs

ification. The results of this study showed that the sulfonated montmorillonite is as effective as powdered activated carbon and it is better than granular activated carbon for removing the trihalomethanes. Also its production cost is lower than for activated carbon. It has high adsorption capacity and short adsorption equilibrium time. Consequently, it is reasonable to use it as an ideal adsorbent to remove the trihalomethanes. Moreover, it could be used to improve the filtration system for the water treatment plants that use chlorine without any changes in the treatment system. The reaction of the chlorine with the organic materials in the swimming pools could lead to a high probability of the trihalomethanes formation. Using the sulfonated montmorillonite in the treatment process of the swimming pools could reduce or eliminate the trihalomethanes and the organic materials. The results showed that the adsorption of the trihalomethanes on the sulfonated montmorillonite matches the Langmuir isotherm.

\section{Conflicts of interest}

There are no conflicts of interest to declare.

\section{Acknowledgments}

The authors appreciate the office of the postgraduate studies of the University of Guilan for the financial support and also the Guilan Science and Technology Park for the laboratory support. Furthermore, they appreciate Dr. Hassan Zavvar Mousavi and Dr. Nematollah Omidikia for their valuable recommendations. Last but not least, they would like to thank Miss Mojgan Solouki, Mrs. Nour Rizk and Mr. Afshin Firoozmanesh for editing their manuscript.

\section{References}

1. J. J. Rook, Water Treat. Exam.1977, 23, 234-243. DOI:10.1049/ep.1977.0128

2. K. Roberts, Trihalomethane Formation and Control. Proceeding of Safe Drinking Water Seminar, Gander, Newfoundland, Canada, 2011.

3. World Health Organization (WHO), Guidelines for Drinking Water Quality, https://www.who.int/water_sanitation_ health/publications/drinking-water-quality-guidelines-4-including-1st-addendum/en/ (accessed: December 22, 2019).

4. United State Environmental Protection Agency (USEPA), National Primary Drinking Water Regulations, https://www. epa.gov/ground-water-and-drinking-water/national-primary-drinking-water-regulations (accessed: December 22, 2019).

5. Center for Disease Control and Prevention (CDC), Disinfection By-Products and the Safe Water System, http://www. cdc.gov/safewater/publications_pages/thm.pdf (accessed: December 22, 2019).

6. B. Lykins, R. Clark, J. Adams, Granular activated carbon 
for controlling THMs (Trihalomethanes) (journal version). U.S. Environmental Protection Agency, Washington, D.C., EPA/600/J-88/051 (NTIS PB89104640).

7. R. J. Potwora, http://www.drinknwaterplus.com/documents/ Trihalomethane\%20removal.pdf (accessed: December 22, 2019).

8. I. N. Najm, V. L. Snoeyink, B. W. Lykins, J. Q. Adams, Am. Water Works Assoc. 1991, 83, 65-76.

DOI:10.1002/j.1551-8833.1991.tb07087.x

9. A. Sakoda, M. Suzuki, R. Hirai, K. Kawazoe, Water Res. 1991, 25, 219-225. DOI:10.1016/0043-1354(91)90032-L

10. A. W. Morawski, M. Inagaki, Desalination 1997, 114, 23-27. DOI:10.1016/S0011-9164(97)00150-1

11. C. Lu, Y. L. Chung, K. F. Chang, Water Res. 2005, 39,11831089. DOI:10.1016/j.watres.2004.12.033

12. P. Gharbani, S.M. Tabatabaei, S. Dastmalchi, S. Ataie, A. Mosenharzandi, A. Mehrizad, Int J Nano Dimens. 2010, 1, 287296. DOI:10.7508/ijnd.2010.04.007

13. R. Zhu, Q. Chen, Q Zhou, Y Xi, J Zhu, H He, Appl. Clay Sci. 2016, 123, 239-258. DOI:10.1016/j.clay.2015.12.024

14. J. Ravichandran, B. Sivasankar, Clays Clay Miner. 1997, 45, 854-858. DOI:10.1346/CCMN.1997.0450609

15. M. Edraki, D. Zaarei, Int. J. Min. Met. Mater. 2019, 26, 86-97. DOI:10.1007/s12613-019-1712-1

16 C. N. Owabor, U. M. Ono, A. Isuekevbo, Adv. Chem. Eng. Sci. 2012, 2, 330-335. DOI:10.4236/aces.2012.23038

17. K. G. Akpomie, F. A. Dawodu, Beni-Suef Univ J. Basic Appl. Sci. 2016, 5, 1-12. DOI:10.1016/j.bjbas.2016.01.003

18. M. Wua, S. Zhao, M. Tang, R. Jing, Y. Shao, X. Liu, Y. Dong, M. Li, Q. Liao, G. Lv, Q. Zhang, Colloids Surf. A. 2019, 575, 264-270. DOI:10.1016/j.colsurfa.2019.05.025

19. C. Morantes, F. Yarza, M. Montes, R. Mercader, G. Curutchet, R. S. Torres, Water Air Soil Pollut. 2020 231, 29-36. DOI:10.1007/s11270-020-4403-7

20. A. Afroozan, A. Mohammad-khah, F. Shirini, J. Appl. Res. Water Wastewater 2015, 2, 150-155.

DOI:10.1016/j.clay.2015.08.001

21. H. Wu, H. Xie, G. He, Y. Guan, Y. Zhang, Appl. Clay Sci. 2016, 119, 161-169. DOI:10.1016/j.clay.2015.08.001

22. O. Acisli, A. Khataee, S. Karaca, M. Sheydaei, Ultrason. Sonochrom. 2016, 31, 116-121.

DOI:10.1016/j.ultsonch.2015.12.012
23. C. Liu, P. Wu, Y. Zhu, L. Tran, Chemosphere 2016, 144, 10261032. DOI:10.1016/j.chemosphere.2015.09.063

24. Q. Yang, M. Gao, Z. Luo, S. Yang, Chem. Eng. J. 2016, 285, 27-38. DOI:10.1016/j.cej.2015.09.114

25. L. Ma, Y. Xi, H. He, G. A. Ayoko, R. Zhu, J. Zhu, Appl. Clay Sci. 2016, 120, 9-15. DOI:10.1016/j.clay.2015.11.010

26. M. Gamba, M. Olivelli, J. M. Lázaro-Martínez, G. Gaddi, G. Curutchet, R. M. T. Sánchez, Chem. Eng. J. 2017, 320, 11-21. DOI:10.1016/j.cej.2017.03.034

27. H. Chen, L. K. Koopal, J. Xiong, M. Avena, W. Tan, J. Colloid Interface Sci. 2017, 504, 457-467.

DOI:10.1016/j.jcis.2017.05.078

28. K. R. Ranjit: Design of Experiments Using the Taguchi Approach: 16 Steps to Product and Process Improvement, John Wiley \& Sons, USA, 2001.

29. F. Shirini, M. Mamghani, S.V. Atghia, j.Nanostructure in Chem. 2012, 3, 2-5. DOI:10.1186/2193-8865-3-2

30. Minitab support webpage, https://support.minitab.com/ en-us/minitab/18/help-and-how-to/modeling-statistics/ doe/supporting-topics/taguchi-designs/taguchi-designs/ (accessed: July 09, 2020).

31. Chlorine disinfection of produce washwater, Michigan state university, https://msu.edu/ brook/publications/aeis/ aeis653.htm (accessed: July 09, 2020)

32. M.H. Haghighat, A. Mohammad-Khah, Asian J. Green Chem. 2020, 4, 297-305 DOI: 10.33945/SAMI/AJGC.2020.3.6

33. S.M. Yakout, Adsorption Sci. Tech. 2010, 28, 601-610 DOI:10.1260/0263-6174.28.7.601

34. S.W. Scheff: Fundamental Statistical Principles for the Neurobiologist, Elsevier Science, 2016.

35. Minitab support webpage, http://support.minitab.com/enus/minitab/17/topic-library/modeling-statistics/doe/taguchi-designs/what-is-the-signal-to-noise-ratio (accessed: December 22, 2019).

36. K. Song, G. Sandí, Clays Clay Miner. 2001, 49, 119-125. DOI:10.1346/CCMN.2001.0490202

37. D. Hillel: Environmental Soil Physics. Academic Press, New York, 1998.

38. G. W. Bailey, J. L. White, T. Rothberg, Soil Sci. Soc. Am. J. Abst., 1968, 32, 222-234.

DOI:10.2136/sssaj1968.03615995003200020021x 


\section{Povzetek}

Trihalometani (THM) nastanejo med procesom kloriranja vode v reakciji med klorom in organsko snovjo. V tej raziskavi smo uporabili montmorilonit (MMT) in njegovo modificirano obliko za odstranjevanje THM iz vode. Optimalne pogoje za najboljšo adsorpcijsko kapaciteto smo opredelili s pomočjo Taguchijevega eksperimentalnega načrta. Rezultati primerjave MMT z njegovo modificirano sulfonirano obliko (SMMT) so pokazali, da je SMMT bolj učinkovit adsorbent kot MMT. Preverjanje pogojev je pokazalo, da so optimalni pogoji za odstranjevanje THM pri $20{ }^{\circ} \mathrm{C}, 10 \mathrm{mg}$ adsorbenta, koncentraciji THM $1 \mathrm{mg} / \mathrm{L}$ in adsorpcijskem času $120 \mathrm{~min}$. Dosežena maksimalna adsorpcijska kapaciteta za $\mathrm{CHCl}_{3}$, $\mathrm{CHBrCl}_{2}, \mathrm{CHBr}_{2} \mathrm{Cl}$ in $\mathrm{CHBr}_{3}$ je bila: $0,49,0,45,0,43$ in $0,38 \mathrm{mg} / \mathrm{g}$ pri $C_{0}=0,10 \mathrm{mg} / \mathrm{L} ; 1,71,1,62,1,56$ in $1,45 \mathrm{mg} / \mathrm{g}$ pri $C_{0}=0,50 \mathrm{mg} / \mathrm{L}$; ter 4,43, 4,35, 4,23 in 3,67 mg/g pri $C_{0}=5,00 \mathrm{mg} / \mathrm{L}$. Adsorpcijo THM smo primerjali med SMMT, uprašenim aktivnim ogljem (PAC) in granularnim aktivnim ogljem (GAC). Rezultati so pokazali, da je SMMT enako učinkovit kot PAC in boljši kot GAC, stroški njegove proizvodnje pa so nižji kot za aktivno oglje. 